\title{
Analysis of the bioethanol production process control
}

\author{
Stanisław Lis", Marcin Tomasik, Stawomir Kurpaska, Jarosław Knaga, Piotr Łyszczarz \\ University of Agriculture in Krakow, Faculty of Production and Power Engineering Krakow, Poland
}

\begin{abstract}
The article presents the analysis of the automatic control of the bioethanol production process intended for biofuel. It presents the formulated general concept of the system and the method of designing a closed control system based on the iterative prototyping procedure. The modeling and the simulation were carried out in the Matlab ${ }^{\circledR}$-Simulink environment. The simulation model of the object was developed based on the experimentally registered characteristics. It has been adjusted, i.e. the compatibility of its behavior with the object it reproduces has been confirmed. Based on the tuned model of the object, a control system model was created, which was the basis for computer simulation which enabled the control algorithm parameters to be established. The final verification of the correct operation of the system was performed with the use of hardware simulation. It was based on entering a negative feedback loop of the virtual control system of the real object elements into the loop. The results of the simulation confirmed the correctness of the adopted design.
\end{abstract}

\section{Introduction}

With the increase of ecological awareness of the automotive market participants, there are a number of initiatives aimed at making transport more environmentally friendly. One of the visible results of such aspirations is the use of fuels obtained from renewable energy sources. This type of fuels includes ethanol obtained from biomass. It is possible to use it directly as fuel (Nissan's e-biofuell cell technology) or as a component in the production of biodieselThe interest in producing this type of fuel for private needs is demonstrated by companies and institutions that have a fleet of vehicles and private individuals, including farmers. It is necessary to introduce ecological regulations [1]. A distillation / rectification column is necessary to produce bioethanol intended for fuel. One of the basic parameters of her work is temperature. A correctly configured control system is necessary for precise control of this process. The study presents a model of such a system formulated in the Matlab $^{\circledR}$-Simulink environment and the selected control unit. The developed control algorithm was verified on the real object.

\section{Scope and aim of the study}

\footnotetext{
* Corresponding author: stanislaw.lis@urk.edu.pl
} 
The purpose of the work was to determine the initial parameters for the integration of system components within the design of the control system for the process of producting bioethanol for biofuel.

The scope of work consisted of: determining the dynamic properties of the control object, formulation of simulation models of the object and the control system, computer and hardware simulation in the Matlab-Simulink environment.

\section{Methodology}

The methodology, according to which the control system was developed, was based on the iterative prototyping procedure. The general concept of control was formulated at the beginning. Next, a simulation model of the control object was developed. It was created on the basis of experimentally determined dynamic characteristics. The model was then adjusted by confirming its compliance with the object it represents.Based on the adjusted model of the object, a simulation model of the control system was created. It was the basis for computer simulation which enabled selection of the control algorithm parameters. The last stage of the procedure was to check the algorithm on the object. For this purpose, the actual elements of the control object - temperature converter (measuring element) and two heaters (actuators) were introduced to the virtual feedback loop of the control unit $[2,3,4]$.

\section{Control object}

He control object constitutes a rectification column. Its general view is shown in fig 1 .

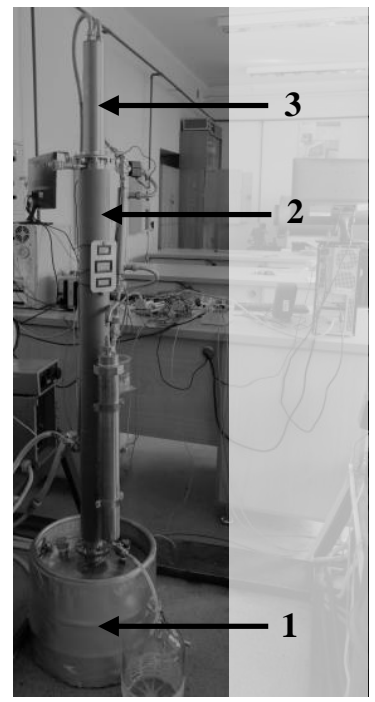

Fig. 1. The rectification column: 1 - tank with heater, 2 - deflegmator, 3 - cooling head

The device consists of a rectified liquid container (1), a defecator (2) placed above it and a liquid cooler (3) located on top of the cooler of the liquid to be obtained. For the distillation/rectification process to occur, it is necessary to provide heat from the heater installed in the tank (1). The core of the column's operation is based on the use of crossflow contact of the liquid freely flowing downwards the deflegmator with the vapors of the rectified mixture. Inside the deflegmator, there are structural elements that increase the surface contact of the liquid with the siad vapors. During the process, about $1 / 4$ of the liquid volume is directed for collection. 


\section{Simulation model of the control object}

The preliminary stage of the development of the control object model was the experimental determination of the step response. For this purpose, the tank was filled with the liquid to be rectified (35 dm3). Next, the voltage applied to the 4000 [W] heater was increased which created an enforcement. The reaction of the object to that enforcement in the form of a change in the temperature of the rectified liquid $\mathrm{T}$ is the desired step response (fig. 2) [2, 3, $4,5]$.

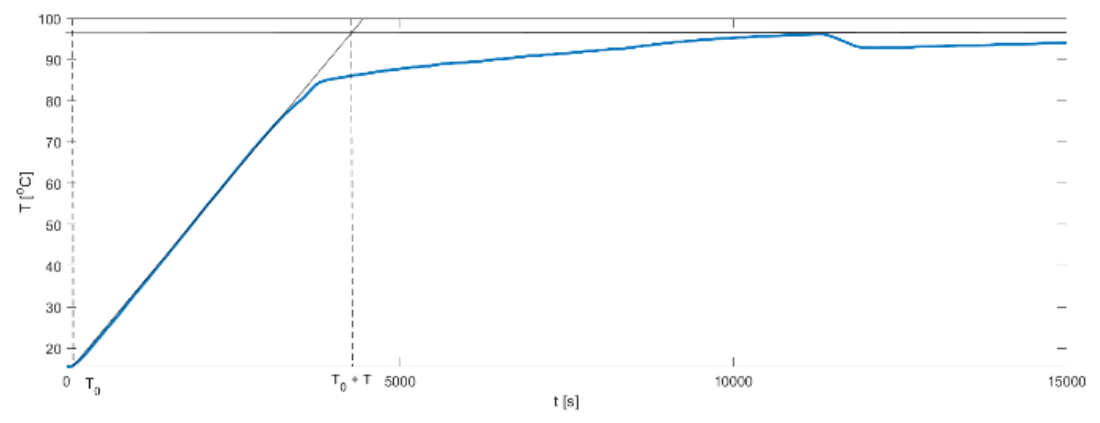

Fig. 2. Step response of the control object

The obtained process (Figure 2) was the basis for the development of the transmittant simulation model G (s), and it is expressed by the dependence 1 .

$$
G(s)=0,0207 \frac{1}{3100 s+1}
$$

where: $\quad s-$ Laplace's operator.

\section{Model of control system in the computer simulation}

On the basis of the object model (dependence 1) a simulation model of the control system was created. It was the basis for computer simulation which allowed the control algorithm to be selected. In the Matlab-Simulink environment, 2 versions of the control system were implemented - in configurations with Relay and PID controllers (fig. 3) [6, 7].

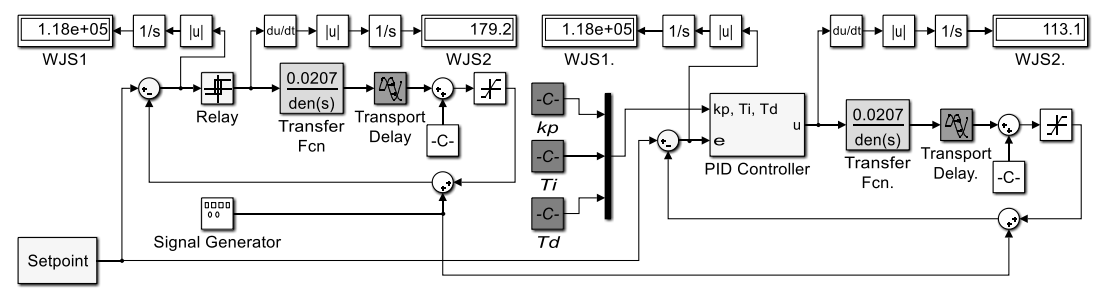

Fig. 3. Block diagram of the integrated simulation models of the control systems with the Relay and the PID controllers

The significance of the most important functional blocks in the diagram is as follows: Setpoint represents a given temperature course, Controller is a regulator transmittance, fcn transfer and transport delay represent the control object. The diagram presents the control loop there is also an additional block, which is not part of the structure of the system - it is a 
signal generator. This block simulates interfering effects. Its presence during simulation tests enables the analysis of the influence of the interfering signal on the quality of control. In addition, the following symbols appear on the diagram: $k p$ - proportional gain, $T i-$ integration time (doubling), $T d$ - differentiation time (advance).

During the computer simulation, the set signal was shaped according to the algorithm that predicts the increase and maintenance of the liquid temperature in the column tank (Fig. 1) at the level ensuring the proper operation of the process. The control quality provided by the modeled systems (Figure 3) was determined by using the integral indexes WJS1 and WJS2 as assessment criteria. Where WJS1 is the integral of the absolute error of regulation (2), while WJS2 is the integral of the absolute value of the derivative of the control signal (3).

$$
\begin{aligned}
& W J S 1=\int_{t_{p}}^{t_{f}}|e| d t \\
& W J S 2=\int_{t_{p}}^{t_{f}}\left|\frac{d u}{d t}\right| d t
\end{aligned}
$$

Where: $e$ - regulation error, $\frac{d u}{d t}-$ derivative of the control signal, $t-$ time, $t_{p}-$ the start of the control time interval, $t_{f}$ - end of the control time interval.

JS2 provides information on the dynamics of the control signal, while the value of the WJS1 indicator informs about the quality of control (the lower the value, the better the control quality is) $[8,9,10]$.

The system operation was analyzed under ideal conditions (without interference) and with regard to the disturbing signal with a sinusoidal waveform with variable amplitude. Based on the conducted simulation tests, it should be stated that the algorithms of the tested regulators during the computer simulation ensured an acceptable control quality. In connection with the above, choosing an easier to implement Relay controller to control the process should be considered.

\section{Model of control system in the hardware simulation}

Hardware simulation confirmed the correctness of the design assumptions and proper operation of the control program, which involved the inclusion of the actual elements of the control object of the virtual control system - temperature converter (measuring element) and two heaters (executive elements) into the feedback loop. The system prepared in this manner formed a prototype of the control system. The block diagram according to which the hardware simulation was carried out is illustrated in Fig. 4 [11]. 


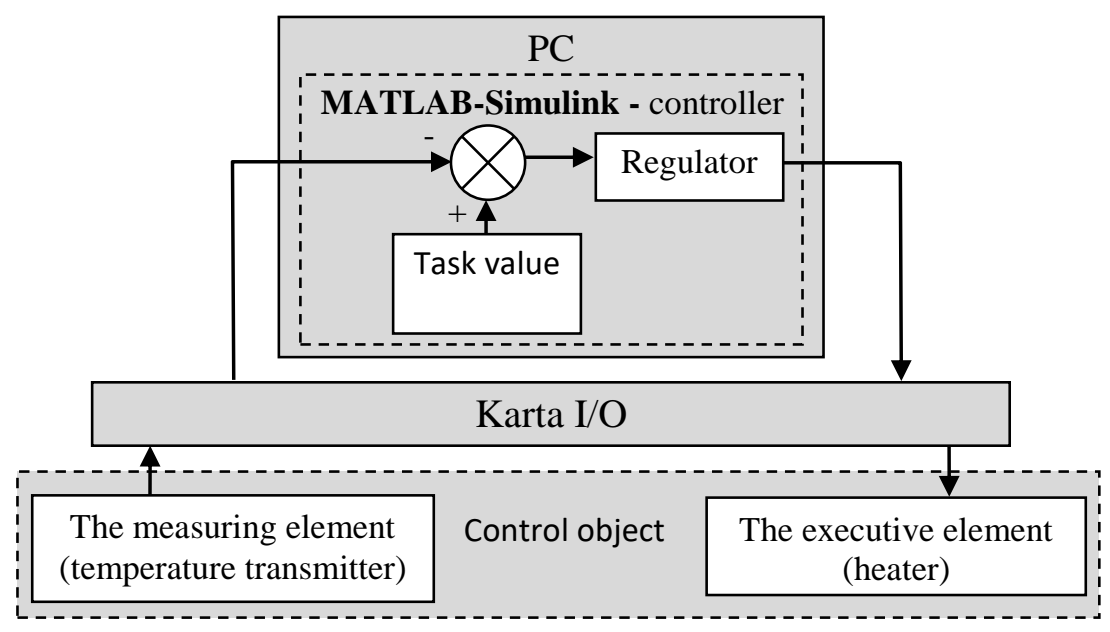

Fig. 4. Block diagram of hardware simulation

The nature of the hardware simulation required a transformation of the model of the control system which is illustrated by the diagram in Fig. 3, which would enable communication with the system's environment. For this purpose, the blocks representing the object model were replaced with input blocks (Analog Input) and Analog output (Analog Output) and scale blocks of input and output signals. (fig. 5).

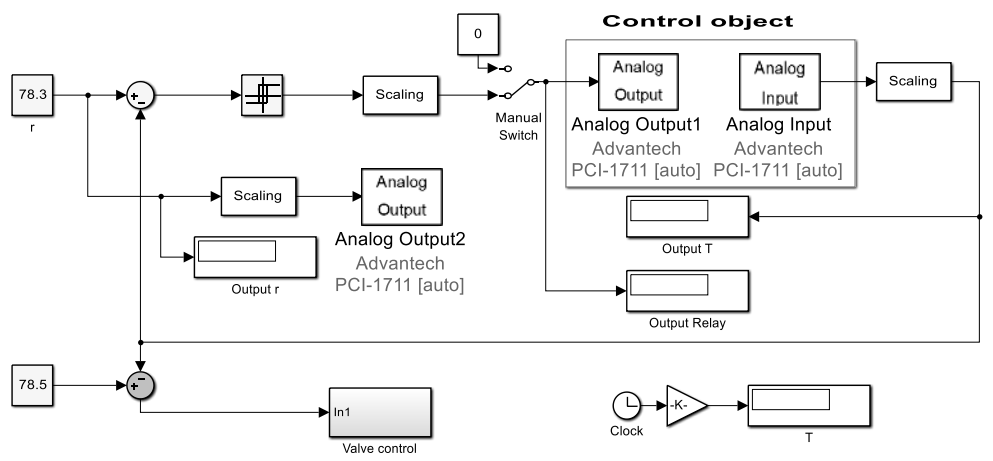

Fig. 5. Block diagram of the model in the hardware simulation

The waveforms of signals for the system being analysed, obtained as a result of hardware simulation, are illustrated in fig. 6 .

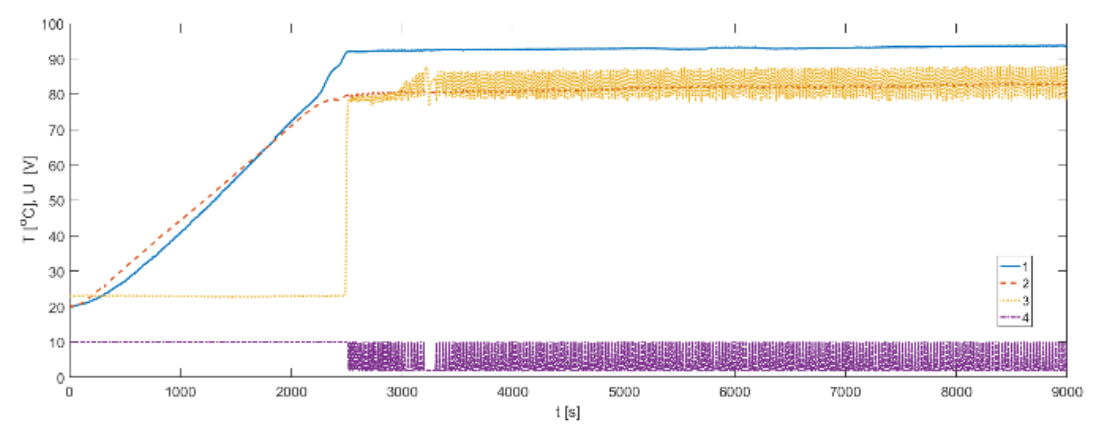

Fig. 6. Results of hardware simulation: 1 - temperature in the tank, 2 - temperature in the defroster, 3 - temperature in the radiator, 4 - control signal of the Relay regulator 
By analysing the illustrated waveforms, it can be observed that the control system prototype correctly generated a feedback effect in regards to the control object - the temperature is maintained at a specific level.

\section{Summary}

The use of simulation models and the iterative procedure assuming the repetition of computer and hardware simulations up to the fulfillment of the prototyped system of conditions, made it possible to determine the initial parameters for the integration of elements included in the system. Computer simulation allowed the selection of a regulator. The hardware simulation made it possible to verify the real-time prototype of the control system. Using the proposed methodology, it was confirmed that the easy-to-implement algorithm of the Relay regulator controlling the temperature in the bioethanol production process guarantees its maintenance at the given level.

\section{Refferences}

1. Wcisło G., Strzelczyk M.: Określenie wpływu rodzaju użytego oleju rzepakowego do produkcji biopaliw na skład frakcyjny RME. Mechanika Czasopismo Techniczne. 5, 291-298 (2012).

2. Tarnowski W., Projektowanie układów regulacji automatycznej. Ciągłych z liniowymi korektorami ze wspomaganiem za pomoca Matlab'a. Wyd. Uczelniane Politechniki Koszalińskiej, Koszalin, ISSN 0239-7129 (2008).

3. Tadeusiewicz R., Biocybernetyka. Metodyczne podstawy dla inżynierii biomedycznej. Wyd. Naukowe PWN, Warszawa, ISBN 978-83-01-17376-0 (2014).

4. Klempka R., Stankiewicz A., Modelowanie i symulacja układów dynamicznych. Wyd. AGH, Kraków, ISBN 83-7464-060-X (2006).

5. Osowski S., Stankiewicz A., Modelowanie i symulacja układów i procesów dynamicznych. Oficyna Wydawnicza Politechniki Warszawskiej, Warszawa, ISBN 837464-060-X (2006).

6. Lis S., Tomasik M., Nęcka K., Drożdż T., Nawara P., Wrona P., Oziembłowski M. Konstrukcja i analiza modelu symulacyjnego układu sterowania piecem indukcyjnym. Przegląd Elektrotechniczny. 12, s. 147-150 (2015).

7. Lis S., Tomasik M., Nęcka K., Oziembłowski M., Nawara P., Kiełbasa P., Ostafin M., Dróżdż T. Analiza wpływu sygnału zakłócającego na jakość klasycznego i neuronoworozmytego sterowania piecem indukcyjnym. Przegląd Elektrotechniczny. 12, 89-92 (2016).

8. Śmierciak P., Ziółkowski E., Comparison of Energy Consumption in the Classical (PID) and Fuzzy Control of Foundry Resistance Furnace. Archives of foundry engineering, ISSN 1897-3310, 3, vol. 12, 129-132 (2012).

9. Śmierciak P., Ziółkowski E., Kryteria optymalizacji w systemach sterowania rozmytego piecami odlewniczymi. Archives of foundry engineering, , ISSN 1897-3310, 2, vol. 14, 95-100 (2014).

10. Śmierciak P., Ziółkowski E., Wpływ wybranych parametrów zakłóceń na jakość klasycznego i rozmytego sterowania piecem oporowym. Archives of foundry engineering, , ISSN 1897-3310, 4, vol. 14, 123-126 (2014). 
11. Kurytnik I. P., Lis S., Drożdż T., Telega A., Metoda szybkiego prototypowania w opracowaniu algorytmu sterowania instalacją solarną. Pomiary Automatyka Kontrola. 2014(5), 325-328 (2014). 